\section{OP2-037 回腸導管尿細菌叢の变遷}

東京医科歯科大学大学院尿路生殖機能学（泌尿器科） 小林 剛, 影山幸雄, 川上理, 增田 均, 矢野 雅隆, 大塚 幸宏, 川野圭三, 高沢 亮治, 浅野 桐子, 木原 和徳 【目的】1）回腸導管患者の尿中細菌叢の变遷を、前回の 調查 (日泌 90 回総会: 2001 年 6 月から 10 月の 34 例) と 比較する。2)術後経過期間と細菌叢との関連を検討する。 【対象と方法】対象は 2003 年 6 月から 9 月に、尿細菌培 養を提出した回腸導管患者 31 例。う方術後 5 年以内は 14 例、 5 から 10 年は 13 例、 10 年以上は 4 例。【結果】1) 回腸導管患者 31 例の分離細菌は 114 株 34 菌種。2) 術後 5 年以内: 56 株 24 菌種、 5 吕 10 年: 49 株 21 菌種、10 年以上: 9 株 6 菌種。培養陰性は 10 年以上の 1 例のみ。 3）分離菌種（複数株以上）の上位 3 種は術後 5 年以内： E. faecalis, E. coli, P. aeruginosa、 5 か ら 10 年 : E. coli, Enterococcus sp. E. faecalis、10 年 以上：E. coli, E. faecalisの 2 種のみ。【結論】1）分離菌種は、全体では 34 種と前回の 27 種を若干上回った。2) 術後経過とともに 分離株、分離菌種ともに減少する傾向にあった。3）長期 経過中に細菌叢は腸管由来の細菌に集約される傾向に あった。4) MRSA (前回 2 株) は今回分離されず、MRSA 感染の拡大はみられなかった。

\section{OP2-038 院内感染制御における泌尿器科医の役 割}

\footnotetext{
神戸大学附属病院感染制御部1), 神戸大学大学院腎泌尿 器科学分野2)

荒川 創一"), 李 宗子1), 木下 承皓1), 重村 克已 ${ }^{23}$, 田中一志"', 川端 岳"2, 守殿 貞夫"2

【目的】院内感染の約 $40 \%$ は尿路感染症であるとされ、国立大学 病院感染対策協議会のガイドラインにも、尿路感染防止・尿道 カテーテル管理が記載されている。泌尿器科医は㽷路感染症に 精通しており、積極的に ICD (infection control doctor)に登録 し、ICN (同 nurse) とともに院内感染防止に提言すべき立場で もある。今回、尿道カテーテル関連感染のサーベイランスの成績 を報告し、泌尿器科医が果たすべき役割について考察を加えた。 【対象と方法】尿道カテーテルの短期留置が多い泌尿器科病棟 （A）と長期留置が多い他臨床科病棟（B）とを対象に、2003 年 2 月から 4 月までに拈りる尿路感染率を集計した。尿路感染 症の診断は、臨床上必要な時点での尿培盖により行った。結果】 $\mathrm{A}$ では感染患者数は 3 例でその分離菌は緑膘菌 2 株、カンジダ 1 株であり、Bでは 8 例で大晹菌、腸球菌、緑膿菌などが見られ た。1000 デバイス・デイで算定した感染率は A で 0 ～10、Bで 9 13 と後者で高かった。考察】泌尿器科では尿道カテーテル 短期留置が多く、感染はよくコントロールされている。長期留置 の多い臨床科では感染率がより高くなる傾向にある。病院全般 の尿路感染対策には、ICN や検查技師とともに泌尿器科医が ICT (感染制御チーム)の一員として関与すべきと考えられた。
}

OP2-039 化腆性脊椎炎を併発した尿路感染症の 2 例

\begin{abstract}
日鋼記念病院泌尿器科", 日鋼記念病院整形外科 ${ }^{2}$, 帯 広厚生病院泌尿器科 ${ }^{3}$, 帯広厚生病院整形外科 ${ }^{4}$

秋野 文臣", 新藤 純理", 榎並 宣裕”, 吉本三徳2),

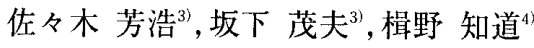

【症例 1】75 歳男性。H12 年 10 月 16 日 TURP 施行。10月 28 日発熱 と炎症反応上昇あり前立腺炎の診断で抗生剂に上る治療を開始し た。11月6 日右下肢の運動障害あり、MRIの結果 L4-L5 間の化膿性 脊椎炎と診断された。生検で得た組織培養で腸球菌が検出され抗生 剂に上る保存的治療を選択。麻㾇の残存なく治癒したが 3 ケ月にわ たる治療を要した。[症例 2】 77 歳男性。H15 年6月 24 日発熟と左側 腹部痛にて受診。CTにて左尿管結石に伴う急性腎孟腎炎と診断し抗 生剂による治療を開始。6月30日背部痛の增炰と右下肢の運動障害 出現し MRIにて Th9 の化膿性脊椎炎と診断された。既往の喘息に よる全身状態の悪化加保存的治潦を選択したか淜易閉塞の併発と循 環動態の增悪により7月7日死亡。病理解剖で炎症による胸椎の広 螌な骨破壊がみられた。考察】化膿性春椎炎証画像と細菌学的検索 にて早期に診断し迅速な治潦を行わなければ重篤な経過を迪ること がある。泌尿器科医か臨床的に経験する事は稀と考方られるが、腎血 腎炎なと腰背部痛を伴う UTI では化膿性春椎炎の併発が判然とせ ず、下肢の神経症状が出現して初めて気つかかれる場合もある。本例は UTIを契機に血行性に春椎への感染が波及したと考元られる。UTI の治療に於いて抗生郕投与でも感染が遷延する例や四肢の神経症状 を呈する場合には化膿性脊椎炎の併発も念頭に置くべきである。
\end{abstract} \section{OP2-040 前立腺針生梌標本における焱症の病理}

\section{鹿児島大学附属病院泌尿器科}

川原元司, 仮屋 知, 榎田 英樹, 久保博幸, 江田 晋一, 西山 賢龍, 中川 昌之

【目的】前立腺炎の病理組織像を評価して、癌陰性例での再生検 の適応判定に利用できるか検討する。【材料と方法】2003 年 3 月 までの 2 年間に評価コア数 6 以上の系統的針生検を施行し、病 理診断が得られた 63 回分、 463 検体 (1 回あたり 7.4 コア)につ いて、癌と炎症に関して鹿児島子防医学研究所 (病理診断責任 医 N.T.) で再評価した。炎症はTrue LD らの病理組織分類法 に準じて location, extent, gradeの subtypeに分類した。採用 例は、臨床的に前立腺炎の所見を認めない 53 82 墄、血清 PSA は 4.1-47.7ng/ml の 58 例であった。[結果]全検体評価で、炎症 は167本（36.1）で認められ、 stromal, focal, mild と判定された ものが最も多く、92本（55.1）を占めた。癌陽性の 21 例中 17 例 (80.9) で炎症か認められ、174 検体中 61 本 (35.1) に炎症陽 性であった。癌陽性の 61 検体中にも 13 本 (21.3) で炎症の共在 を認めた。癌陰性 42 生検では、35 生検 (83.3) で炎症を認め、 281 検体中 106 本 (37.7) で炎症陽性であった。3検体で認めた grade/severeはすべて癌㓌性例であった【結論]癌検出を目的 とした前立腺針生梌標本中に認められる炎症像は軽度の炎症 所見が多く、その頻度は高い。癌陽性群と陰性群で炎症の病理 組織像に差はなく、高度な炎症を認女る場合を除き、炎症の有 無を再生検の適応の判定に利用することは不適と思われた。 